\title{
特集／テイッシュウェルデイング
}

\section{レーザー血管吻合法の有用性について Effect of laser assisted vascular welding}

\author{
二宮 淳一, 庄司佑, 田中 茂夫 \\ 日本医科大学胸部外科
}

Junichi NINOMIYA, Tasuku SHOJI and Shigeo TANAKA

Department of Thoracic \& Cardiovascular Surgery, Nippon Medical School

\begin{abstract}
要 旨
レーザー血管吻合法をNd-YAG レーザーを用いた contact method で動脈奏験で確立した 後に，臨床63例に応用した。内胸動脈一前下行技吻合の CABG 4 例は全例レーザー吻合に成 功し, 開存率も100\%で，4年の遠隔期にも虚血症状起認めていない。乳児の大動脈縮窄部切 除后の端々吻合では術后の吻合部の成長が認められた。また末消血管吻合や内シャント術を レーザー吻合した群でも 6 ヶ月后 1 例の閉塞を認めたのみで，かつ7年后の開存率も77\%と良 好であった。

キーワード：Nd-YAGレーザー, 血管昒台, 人工血管, 遠隔成績
\end{abstract}

\begin{abstract}
Low energy Nd-YAG laser was utilized to make vascular welding with contact method. After success and good patency for vascular welding in canine experience, sixty three patients with 4 ischemic heart disease, 2 coarctation complex, 39 peripheral occlussive disease and 18 chronic renal failure were received laser vascular welding. these weldings successed in all cases except one and patency rate was excellent. The anastomotic sites of the aorta in infants were growable. Late patency rate was also excellent because of $77 \%$ seven years later.
\end{abstract}

Key words: Nd-YAG laser, vascular welding, biological grafts, late result

1. 目的

約30数年前に、レーザーという新しい光が発振さ机て 以来, この光は精密計測・通信・加工・エネルギー開発 などに広く普及したが，医学分野への応用も近年めざま しいものがあり，新しい応用方法と手技か開発されてき た，心臟血管外科におけるレーザーの応用も散発的に報
告1ーらがされているが，解決されなければならない多く の問題が山積みしている。そのため著者らも1986年以来, 心瀻血管外科領域へのレーザーの応用を研究してきた。 今日までレーザーを用いて血管吻合，血管形成，不整脈 治療, ASD 作製, 心室流出路狭窄解除, 心筋内血行再 建などの奏験及び臨床研究を行ってきた ${ }^{7-9) 。 ~}$ 


\begin{tabular}{lc}
\hline 1. Atherosclerotic obstructive disease : & 39 cases \\
2. Chronic renal failune : & 18 cases \\
3. Ischemic heart disease : & $(5)$ \\
4. coarctation complex : & 4 cases \\
\end{tabular}

( ) : Number of vasc. welding by laser \& collagen

今回, 著者らのレーザ一血管吻合の有効性について逗 隔成績を含めて検討し，興味ある知見を得たので報告す る。

\section{2. 方法及び対象}

レーザー吻合法は著者らがこれまで報告してきた方

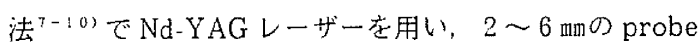
で出力 $1 \sim 3 W$ ，照射時間0.5 5 秒 /回で, 原則とし $て$ contact methodにて行った。又吻合部の補強の意 味で適宜 collagen を吻合部に使用し，レーザーにて接 台した。

この方法にて，まず成犬38頭を使用して，気管内括管 全湫下に, 頸動脈, 大腿動脈又は冠状動脈を路出した。 頸動脈之大腿動脈は切断后に逴接端々吻合するか，又は biological grafts interposeして端々吻合を行った。 冠状動脈は beating 下に左内胸動脈と LAD 端側吻 合するか，又は biological graft LAD と左内胸動 脈間にinterposeして吻合した。吻合の詳紐はすでに報 告フー10) しているのではぶく。

この夷験結果をもとに，臨床応用を行なった。臨床の 対象は，虚血性心疾患にて内胸動脈一左前下行バイパス (CABG) 4 例, 乳児の大動脈縮窄複合で coarctectomy 娞に胸部下行大動脈を端々吻合した 2 例，腹部・四肢血 行再建又は㹂不全に対する shunt 術57例の台計63例で ある(表 1 )。

これら症例の初期成績から術後 1 年以上 7 年までの遠 隔成績につき検討を加えた。

なお使用した biological graftsは heparinized biological graft (1) と Bioflow graft である。

\section{3. 成 績}

\section{实験結果}

大腿動脈又は頸動脈での末消血管レーザー吻合の結果 は初期の biological graft 吻合を行なった 2 例を除き

\section{表 2 Experimental results}

1. Peripheral arteries

Biological graft welding success : $92 \%(22 / 24)$ patency : $100 \%(22 / 22)$

Native arterial welding success : $100 \%(10 / 10)$ patency : $100 \%(10 / 10)$

2. Coronary artery

Laser welding of IMA to coronary artery success : $100 \%(6 / 6)$ patency : $83 \%(5 / 6)$ Laser welding of biological graft to coronary artery success : $83 \%(5 / 6)$ patency $: 100 \%(5 / 5)$

全例に成功し，その開存率は100\%であった。また CABG においては，ITAの直接吻合は100\%成功し，1例が術 後開塞を来たした。biological graftを使用した群では 成功率83\%であったが，開存率は100\%と良好であった (表 2 )。

また術后 3 年目に犠牲死させた成犬の吻台部の血筐内 視鏡所見を図 1 に示寸が，物合部線には全く過形成もな く, smoothで，良好な開存所見を呈していた。

\section{䠦床結果 :}

全体でのレーザー吻合街の成功率は100\%であり，又 早期開存率も100\%であった。

次に各グループの成績を述べる。

ITAを用いて LAD にレーザー吻合を行った 4 例は。 この吻合も比較的容易で，100\%の開存が得られ，術后 の冠状動脈造影にて良好な開存のみならず，吻合部の過 形成等もなく，徒後最長 4 年の時点でも運動負荷テス卜 にても全く虚血症状を認めていない（表 3 )。図 2 に術 中レーザ一吻台時の写真と術后の造影所見を示したが， 


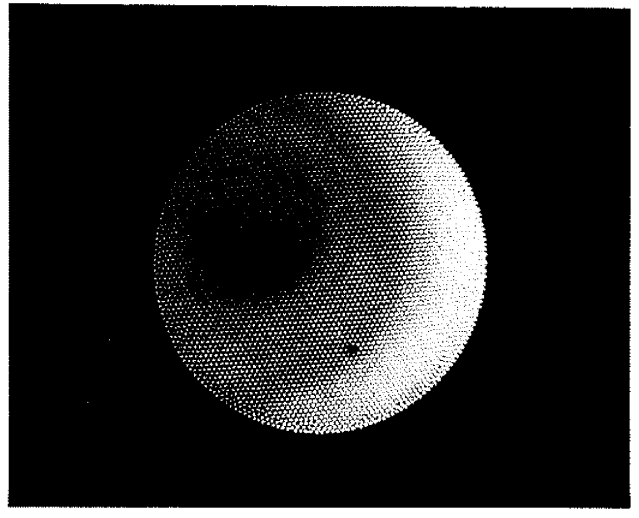

図 1 Laser vasculor welding術後 3 年目の吻合部 血管内視鏡所見

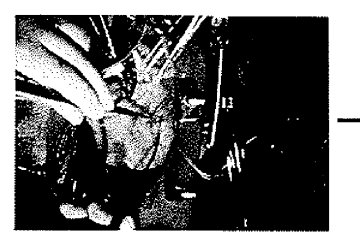

Op.Procedure

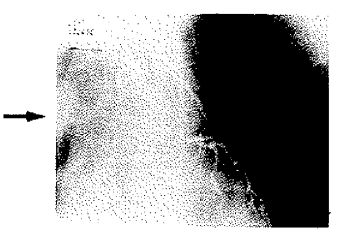

Postop. CAG
図 2 Laser assisted CABG 0 術中写真と術後 CAG
表 3 Laser assisted CABG

A anastomofic site

- LITA-LAD $(n=4)$

- Postop. graft patency : 100\%

- Quality of anastomotic sites : excellent

- No ischemic sign on exercise

4 year follow-up period

Diameter

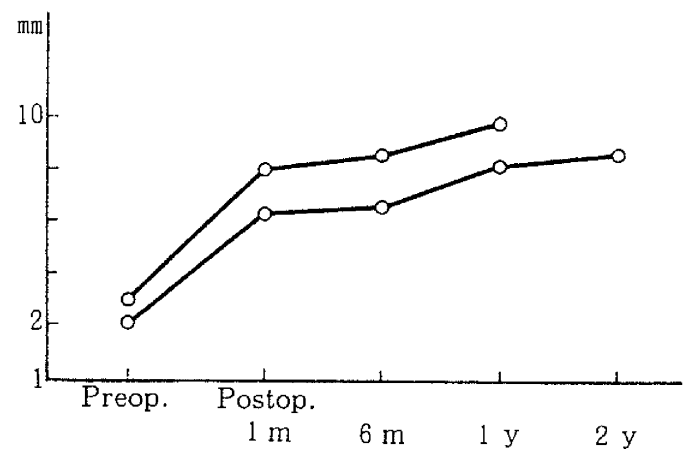

図 3 Changes of Anastomotic sites after Laser welding of thoracic aorta

表 4 Surgical Procedures

Arterial occlusive diseases $(n=39)$

11 io-femoro-popl iteal bypass : 2 cases

composite graft (E-PTFE+biograft)

llio-femoral bypass

: 3 cases

Femoro-femoral bypass

: 6 cases

Femoro-popliteal bypass

: 20 cases

composite graft (SVG + biograft : 10)

: 5 cases

Femoro-tibial bypass

composite graft (SVG+biograft : 4)

composite graft (SVG + biograft : 4)

Aorto-IMA bypass

: 3 cases

Chronic renal failure $(\mathrm{n}=18)$

Radial art-superficial v. bypass

: 11 cases

SVG bypass in forearm

: 5 cases

SVG bypass in thigh

: 2 cases

渾足出来る結果であった。

乳児の coarctectomy 後の大動脈の端々吻合は，将 来の吻合部の成長を期待して行った。術後の定期的な 2 $\mathrm{DECHO}$ による観察で，2 例共に有意に吻合部の成長 を認めた（図 3 )。
腹部・四肢血行再建之 shunt 術を施行した57例の術 式は表 4 に詳細を示す。手術死亡はなく, 術後 6 ケ月で shunt の閉塞を来した 1 例を除くと $100 \%$ の開存が得ら れた。その後経年的に開存率は減少傾向を示したものの 術後 7 年で $77 \%$ の開存を得ており（図 4 ）, 著者らの手 


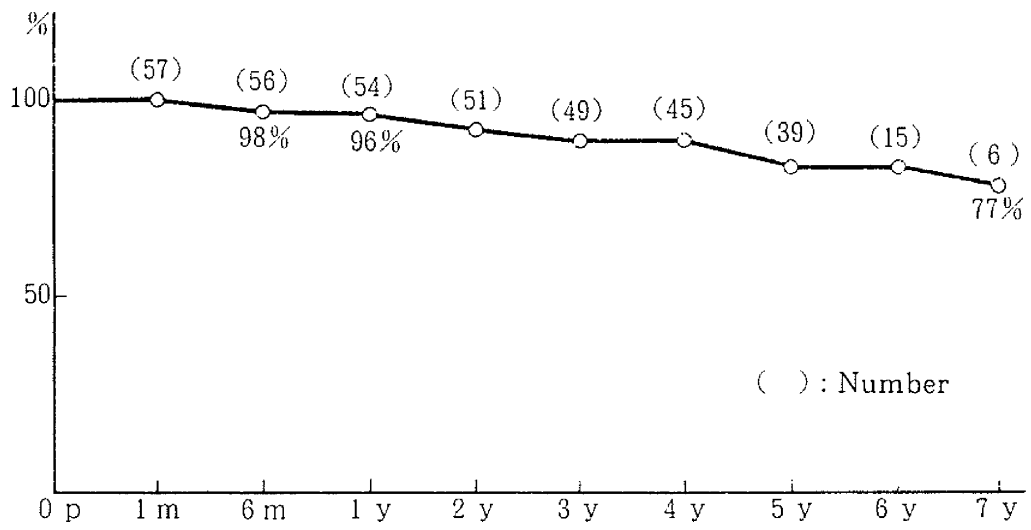

圈 4 Postoperative patency rate after peripheral vascular weldings

縫い吻合の成績に比べて满足出来るものであった。

\section{4. 考 察}

1）血管吻合法の種類とレーザー

現在行われている血管吻合法は大別して，(1)手縫い法， (2)手縫い法以外の方法の二つに分けられ，手縫い法以外 の方法としては@tube 又はcuff ligation法, (b) staple 法, (Cring-pin法, (d) clip法, (e)接着剤の応用, (f)電気 凝固法，执よびタレーザーの応用法などがある。そのう ち血管吻合器や他の器具などを用いる方法は直径 1 2 m以以の血管では统用しにくく，したがって現在では手 縫い法がもっとも確実な力法であり，利用範国も広く、 安全である。しかし，手縫い法は手術手技が難しく，熟 練を要するため，また誰にでもできるというものではな い。また手䋖い法によって㽗合された血管の縫合部を組 織学的に観察すると, 針によって生じた穴は㠜血によっ て閉塞されるがこの穴を中心に急性炎症細胞が浸潤し，

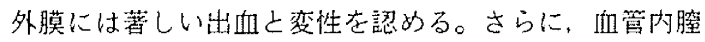
に露出した縫台米は内皮細胞に上って完全に被覆される までに2 週間以上を要し，しかもその系を中心に肉芽組 織が形成され，線維化されて肥厚し，和管内䐦に盛り上っ てくるため，血管内臸に露出する總が多け机ばそ扎だけ 直管も開塞されやすくなる。したがって，古くはServant ら (2) も指摘している上うに，縫合系の数はできるだけ 少なくした方が良い結果が得られるもの上考えられる。 またこの縫合法の欠点を補うもの上してレーザーによ る方法がJainら”の微小血管吻合術が報告されて以来, 著者らを䓠めていくつかのレーザー血管吻合法が報告さ れてきた ${ }^{4.5 .87 。 ~}$

\section{2) レーザーの種類と特徵}

血管吻合に用いられるレーザーの種類には $\mathrm{CO}_{2}$ 。 Nd-YAG, Argon, 半導体レーザ一等があり，そ饥ぞ
れ特徵を有している。その特徵は主にレーザー光の波長 に由来して生じるもので, $\mathrm{CO}_{2}$ レーザーは深達度が浅く， 水に吸収されやすいため比較的壁の薄い血管や微小血管 に用いられるが，その照射エネルギ一量は研究者により 異なっている。すなわち，1.5〜2.0 J/mm²のエネルギー のレーザー照射が適正である上の報告もあれば, 30〜100 $\mathrm{mW}$ の出力で照射したときもっとも满足すべき結果を 得たとの報告”もある。こ扎らの成績のバラツキは一つ には血管組織性状の違いであり，レーザーエネルギーが 照射さ机た部位の温度, 条件によって異なるものと考元 られる。この点は他の Argon やNd-YAGレーザ一等 による血管吻台等にも言えることである。Argonや Nd-YAGレーザーは波長が長いため深達度が $\mathrm{CO}_{2}$ に比 较して深い。そのため吻合部の强度は增すが, 微小血管 すなわち1.0mm未潇の䀛合に使用する場台には工夫が必 要である。しかし実際の臨床では $1.0 \mathrm{~mm}$ 未満の血管吻枲 は心臟血管外科領域では，非常に稀であり必要性は少な い。そのため，著者らは，Nd-YAGレーザ一在使用し て，しかも contad methodにて行っているため，レー 计一照射条件は常に一定であり，安定した成績老得てい る重要な点である。

さらに著者らは，Nd-YAGレーザーによる吻合方法

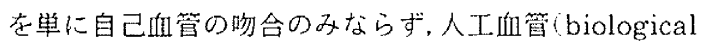
grafts）との吻合も可能であることを，世界で初好て報 告 ${ }^{102}$ し、さらに今回の結果からも臨床例に执いても良 好な成績を德隔期にもおさめることができた。

3) レーザー血管吻合の利点

著者らのNd-YAGレーザーを用いた血管吻合の経験 から，本法の利点は，(1)血栓形成がない，(2)不良・過剩 肉芽形成が少ない，(3)開存率が良好である，(4)很傷治症 が促進される，(5)吻合部の成長が期待出来る，(6)操作が 簡単で熟練を要しないなどが主たるところである。これ 
表 5 Indication of Laser vascular welding

\begin{tabular}{l} 
Small vascular anastomosis \\
\hline - coronary artery \\
- peripheral artery \\
- branches of aorta \\
- others \\
Pediatric vascular anastomosis \\
- original B- $T$ shunt \\
- coarctation or interruption repair \\
- arterial switch operation \\
- others
\end{tabular}

らから冠状動脈バイパス術，末消血管吻合術及び小児の 成長を期待する血管吻合術に Nd-Y AGレーザーを用い て行い良好な結果を得た。現在著者らは心茼血管外科に おけるレーザー䢐管吻合の適応は表 5 の上うに考えてい るが，今度本法を積極的に応用してゆくこよにより，そ の適応の应大に努めたい上考えている。

\section{5。結 語}

レーザーによる vascular welding の方法を動脈実駼 で確立したのちに、臨床63例に応用した。この方法は， 従来の手縫い吻合に比して吻合部の過形成もなく，内面 が平滑であり，かつ小児例では吻合部の成長も期待でき る。また逗隔成績の上からも韭常に有効な力法であると 考えられた。

\section{文 献}

1) Jain KK and Gorish W: Repair of small blood vessels with the Neodymium-YAG laser : A preliminary report. Surgery, 85:684-688, 1979

2) Mirhoseini M, and Cayton NM : Revascularization of the heart by laser. J Microsurgery. $2: 253,1981$

3) Choy DSJ and Stertzer SH : Transluminal laser catheter angioplasty. Am J Cardiol, 50: 1206, 1982

4) White RA, Kopchok, G, Donayre C et al : Comparison of laser welded and sutured arteriotomies, Arch Surg 121:1133-1135. 1986

5) Okada M, Shimizu K, Ikuta $H$ et al. :A new method of vascular anastomosis by low energy $\mathrm{CO}_{2}$ laser : experimental and clinical study, Kobe j Med Sci 31:151 168, 1985

6) Seksena $S$ and Gadhoke A : Laser therapy for tachyarrhythmias: A new frontier, Pace 9 : $531 \sim 550, \quad 1986$

7 )二宮淳一, 庄司结, 田中茂夫他，心臟血管外科人 の Nd-YAG レーザーの応用, 日レーザー医誌 $9: 37 \sim 40,1988$

8) Ninomiya J, Shoji T, Tanaka $\mathrm{S}$ et al : Laser vascular welding in biological grafts, ASAlo Transaction $35: 208 \sim 211,1989$.

9 ）二宮淳一, 庄司 佑. 田中茂夫他, Laser 之 collagen 在併用した vascular welding，脈管学 $32: 1125$ $\sim 1127,1992$.

10）二宮澋一, 庄司佑, 田中茂夫他, Laser welding の研究, 特に人工血管吻合の可能性について。人工 臟器 $18: 414 \sim 416,1989$

11) Noishiki $Y$, Miyata $T$ and Kodaira $K$ : Development of a small caliber vascular graft by a new cross-linked method incorporating slow heparin release collagen and natural tissue compliance. ASAlo Transaction $32: 114 \sim 119$, 1986

12) Servant JM, Ikuta $Y$, Harada $Y: A$ scanning electron microscope study of microvascular anastomosis. Plast Reconstr, Surg $57: 329$. 1976 